\title{
Using Empirical Research to Design Government Citizen Participation Processes: A Case Study of Citizens' Roles in Environmental Compliance and Enforcement
}

\author{
David L. Markell \& Tom R. Tyler
}

\section{INTRODUCTION}

The issue of what role(s) citizens should play in governance is one of many outstanding, oft-debated questions about the appropriate structure and operation of our institutions of governance. ${ }^{1}$ Some commentators have argued strongly for increasing citizens' opportunities to participate in government decision-making processes and to shape government outcomes. $^{2}$ Others have taken considerably more skeptical positions

\footnotetext{
* Steven M. Goldstein Professor, Florida State University College of Law, and University Professor, Psychology Department, New York University, respectively. Professors Beth Burch, Jon Klick, Wayne Logan, Greg Mitchell, and Joseph Sanders contributed very helpful comments on drafts of this article. We also are grateful for the insightful suggestions we received in presenting the paper during the November 2007 Conference on Empirical Legal Studies at NYU Law School. Stephanie Weisbrod, FSU College of Law '09, and Miriam Coles, FSU College of Law '08, provided excellent research assistance. Judith Brodkin, Sarah Meyer, Jamila Gooden (all FSU College of Law '07), and Avital Mentovich (NYU graduate student in psychology) researched and compiled the lists of individuals and organizations we notified about our survey and helped us to track responses. We are grateful to them for their hard work on this part of the project.

1. This question is addressed in the extensive literature about the legitimacy of the administrative state, among others. See, e.g., Mark Seidenfeld, A Civic Republican Justification for the Bureaucratic State, 105 HARV. L. REV. 1511, 1516-28 (1992). For a few articles that focus particularly on the role of citizens in domestic governance in the United States, see, for example, Jody Freeman, The Private Role in Public Governance, 75 N.Y.U. L. REV. 543, 546 (2000); Sidney A. Shapiro, Administrative Law After the Counter-Reformation: Restoring Faith in Pragmatic Government, 48 U. KAN. L. REV. 689, 689-90 (2000); Richard B. Stewart, Administrative Law in the Twenty-First Century, 78 N.Y.U. L. REv. 437, 439-40 (2003); Richard B. Stewart, The Reformation of American Administrative Law, 88 HARV. L. REV. 1669, 1672-73 (1975). The appropriate role for citizens in governance is also the focus of an ongoing dialogue in the international arena. See, e.g., ANNE-Marie Slaughter, A New World ORdER 104-30 (2004); Steve Charnovitz, Two Centuries of Participation: NGOs and International Governance, 18 MICH. J. INT'L L. 183, 274-78 (1997) (listing potential benefits and concerns associated with empowering non-governmental organizations (NGOs) to participate in governance).

2. Some of the rationales offered for greater citizen involvement include enhancing government legitimacy and strengthening government performance. See generally David Markell, "Slack" in the Administrative State and Its Implications for Governance: The Issue of Accountability, 84 OR. L. REV. 1, 10 (2005) (identifying and summarizing several such rationales).
} 
about empowering citizens. ${ }^{3}$ The skeptics are concerned that citizen engagement will cause delays and otherwise lead to inefficient decisionmaking, ${ }^{4}$ empower the already empowered and thereby do little to enhance legitimacy or more broadly-based decision-making, ${ }^{5}$ and elevate the voice of "squeaky wheels," thus undermining the role expertise should, and otherwise would, play in agency decision-making. ${ }^{6}$

Despite the concerns that skeptics and others have raised, the reality is that an enormous number and variety of citizen participation mechanisms exist in domestic and global governance. ${ }^{7}$ Further, in recent years, support for citizen engagement has made creation of new hybrid approaches intended to increase public involvement a regular feature of the governance landscape. ${ }^{8}$ Congress has been receptive and has adopted several policies in recent years intended to increase the role of citizens in governance. ${ }^{9}$ Government agencies have pursued the same tack. ${ }^{10}$

3. See, e.g., Jerry L. Mashaw, Due Process in the Administrative State 23, 29 (1985) ("Participation has costs as well as benefits."); Jim Rossi, Participation Run Amok: The Costs of Mass Participation for Deliberative Agency Decisionmaking, 92 Nw. U. L. REV. 173, 177 (1997) (stating "political theorists have often suggested that mass participation is not always a positive good for democracy").

4. See, e.g., MASHAW, supra note 3, at 23 (noting the "participatory approach [] has serious limitations); Rossi, supra note 3, at 177-78 ("[T] he increase in mass participation itself may have adversely affected the quality of bureaucratic decisionmaking.").

5. See MASHAW, supra note 3, at 24 ("[I]nterests that are substantially affected might, because of lack of resources or organization, fail to participate effectively in administrative forums."); see also Michael S. Greve, Private Enforcement, Private Rewards: How Environmental Citizen Suits Became an Entitlement Program, in ENVIRONMENTAL Politics: PUBlic Costs, PRIVATE Rewards 107-08 (Michael S. Greve \& Fred L. Smith, Jr. eds., 1992) (arguing that citizen participation through citizen suits is a tool for self-interested special interest groups).

6. See MASHAW, supra note 3, at 24 ("[C]ertain interests, because of their intensity, resources, and organization, will come to dominate even an open decision-making process."). Other concerns about NGOs and their participation in governance have been raised as well. Accountability (or lack thereof) has been a prominent topic. For treatment of the "dark side" of civil society, see ARIEL C. ARMONY, THE Dubious LinK: CiviC ENGAGEMENT AND DEMOCRATIZATION 56-103 (2004).

7. For information on the field we study in this article - public involvement in environmental regulation - see, for example, U.S. EPA, OfFICE OF POLICY, ECONOMICS \& INNOVATION, PUBLIC INVOLVEMENT POLICY OF THE U.S. ENVIRONMENTAL PROTECTION AGENCY 2 (2003), available at http://www.epa.gov/publicinvolvement/pdf/policy2003.pdf.

8. For example, Congress has encouraged negotiated rulemaking, and, more recently, has promoted e-rulemaking. Cary Coglianese, Citizen Participation in Rulemaking: Past, Present, and Future, 55 DuKE L.J. 943, 943-47 (2006) [hereinafter Coglianese, Citizen Participation]; Cary Coglianese, Internet and Citizen Participation in Rulemaking, 1 J.L. \& POL'Y FOR THE INFO. SOC'Y 33, 44-47 (2005) [hereinafter Coglianese, Internet and Citizen Participation]. For treatment of institutions in a variety of countries that provide for different levels of citizen participation, see Christopher S. Elmendorf, Advisory Counterparts to Constitutional Courts, 56 DUKE L.J. 953 (2007). For a brief survey of the increasing role of NGOs in international diplomacy, and the different types of NGOs, see Kal Raustiala \& Natalie L. Bridgeman, Nonstate Actors in the Global Climate Regime, (UCLA Sch. of Law Pub. Law \& Legal Theory Research Paper Series, Research Paper No. 07-29), available at http://ssrn.com/abstract=1028603.

9. See, e.g., Coglianese, Citizen Participation, supra note 8, at 943-45; Coglianese, Internet 
Rhetoric in support of extensive and meaningful public engagement has not necessarily matched reality. Public involvement is not something that can be taken for granted. With even relatively simple forms of involvement in government processes (for example, voting in elections), encouraging public participation has proven difficult. ${ }^{11}$

This project is animated by our desire to improve understanding of approaches that are likely to be effective in engendering enhanced public involvement. ${ }^{12}$ A key threshold issue involves determining the types of features that are likely to be effective in encouraging citizen involvement in governance. That is, what types of government procedures and institutions will motivate citizens to come forward and be part of government decision-making? ${ }^{13} \mathrm{We}$ are at an early stage of understanding concerning these issues. As Professor Mariano-Florentino Cuéllar has noted, we still have a great deal to learn about both "actual

and Citizen Participation, supra note 8, at 42-43; Rossi, supra note 3, at 174-75. The Freedom of Information Act (FOIA) provides an opportunity for citizen engagement that was intended to enhance government accountability and educate the citizenry, though some have claimed it is unnecessary while others have questioned its effectiveness. See, e.g., Seth F. Kreimer, The Freedom of Information Act and the Ecology of Transparency (Univ. of Pa. Law Sch. Pub. Law \& Legal Theory Research Paper Series, Research Paper No. 08-06), available at http://papers.ssrn.com /abstract=1088413.

10. See, e.g., U.S. EPA, supra note 7, at 1 . On the other hand, national security concerns have contributed to recent initiatives to restrict access to certain types of information. See, e.g., Michael Fitzpatrick, Code Orange: Will It Be Used to "End-Run" Federal Rulemaking Requirements?, 29 ADMIN. \& REG. L. NEWS 11, 11 (2004) (suggesting that a variety of laws passed in response to the terrorist attacks of September 11, 2001, implicate the availability of information to the public).

11. For example, only $42 \%$ of the voting-age population reported voting in the 2002 congressional election; only $41.9 \%$ of eligible potential voters voted in the 1998 congressional elections, which was a record low. JenNifer CheESEMAN DAY \& Kelly Holder, U.S. Census Bureau, Voting AND Registration in the Election of November 2002 14-15 (2004), available at $\mathrm{http}: / / \mathrm{www}$. census.gov/prod/2004pubs/p20-552.pdf.

12. The question of the appropriate level of public involvement in governance is beyond the scope of this effort. There are pros and cons to different levels of citizen participation in different governance structures. See, e.g., Rossi, supra note 3. Citizen confidence in processes may increase their willingness to defer to them. This idea of voluntary deference is central to emerging models of self-regulation, but requires that the procedures used are experienced by those involved as appropriate and reasonable mechanisms. See generally Marius Aalders \& Ton Wilthagen, Moving Beyond Command-and-Control: Reflexivity in the Regulation of Occupational Safety and Health and the Environment, 19 LAW \& POL'Y 415 (1997); Cary Coglianese, Assessing Consensus: The Promise and Performance of Negotiated Rulemaking, 46 DuKE L.J. 1255 (1997); Bradley C. Karkkainen, Collaborative Ecosystem Governance: Scale, Complexity, and Dynamism, 21 VA. ENVTL. L.J. 189 (2002).

13. While our focus will be on environmental disputes, the issue of procedural acceptability comes up wherever there are hotly contested questions at issue. In the past, one area that has been the focus of many efforts to identify acceptable procedures for resolving disputes is family court, which deals with divorce, child custody, and child support payments. For a review of this topic, see Penelope Eileen Bryan, Constructive Divorce: Procedural Justice and Sociolegal REFORM (2005). 
and potential public participation" in governance. ${ }^{14}$ Additional work is needed to refine and enhance our grasp of the nature of and reasons why citizens prefer different types of decision-making processes. ${ }^{15}$

As scholars from various disciplines continue to wrestle with the issue of how to engage the public in government processes, our theoretical frame of reference lies in the psychology literature. That literature pursues an ongoing exploration of the relative influence of "distributive justice" and "procedural justice" concerns in shaping citizen perspectives on different governance approaches. ${ }^{16}$ The concept of "distributive justice" focuses on the fairness or appropriateness of a procedure's outcomes. ${ }^{17}$ In contrast, "procedural justice" involves the extent to which citizens value a process because of its procedural features. $^{18}$

The emerging body of work on the relative salience to citizens of distributive and procedural justice in different types of processes suggests that citizens value both types of justice. As one of us has suggested: "[ $t$ ]he expanded model [of social justice] recognizes that people are concerned about how decisions are made as well as about what those decisions are"- the distinction between substantive and

14. Mariano-Florentino Cuéllar, Rethinking Regulatory Democracy, 57 ADMIN. L. REV. 411, 417 (2005). It is also the case that a wide variety of factors may influence the extent of public involvement in any governance issue. See, e.g., David L. Markell, Understanding Citizen Perspectives on Government Decision Making Processes as a Way to Improve the Administrative State, 36 ENVTL. L. 651, 655 (2006) [hereinafter Markell, Understanding Citizen Perspectives] ("A potentially valuable step in fostering citizen participation in government decision making processes is to incorporate in these processes features that are important to citizens. Processes that citizens value are likely to be processes that citizens use and that enhance citizen confidence in government, while processes with features that citizens find unsatisfactory are likely to be processes that do not engender meaningful citizen input .....").

15. Gerald S. Leventhal, What Should Be Done with Equity Theory? New Approaches to the Study of Fairness in Social Relationships, in SOCIAL EXCHANGE: ADVANCES IN THEORY AND RESEARCH 27, 39 (Kenneth J. Gergen et al. eds., 1980). Others have echoed the need for more research and analysis concerning other aspects of the issue of government operations and legitimacy. See, e.g., James L. Gibson et al., The Supreme Court and the US Presidential Election of 2000: Wounds, Self-Inflicted or Otherwise?, 33 BRIT. J. POL. SCI. 535, 538, 555 (2003) (noting that "we have a long way to go in understanding the relationship between institutional performance and legitimacy" and that "only with more valid measures of institutional legitimacy can we make progress in unraveling the causal linkages between performance and legitimacy").

16. See, e.g., TOM R. TYler ET AL., SOcial JuStice IN A DiverSe SOCIETy 85 (1997).

17. See, e.g., id. at $45-74$.

18. Author Tom Tyler defines "procedural justice" as involving participants' satisfaction with decision-making processes. Tom R. Tyler, What is Procedural Justice?: Criteria Used by Citizens to Assess the Fairness of Legal Procedures, 22 LAW \& SoC'Y REV. 103, 104 (1988) [hereinafter Tyler, What is Procedural Justice?]; see also Leventhal, supra note 15, at 39 ("[A] justice rule is defined as a belief that allocative procedures are fair when they satisfy certain criteria. This type of justice rule is referred to as a procedural rule, to distinguish it from distribution rules ...."). We acknowledge it is not always possible to completely disentangle the concepts of distributive justice and procedural justice and that is the case for our results. 
procedural justice. ${ }^{19}$ This work has, in addition, begun to shed light on the relative importance of procedural and distributive justice to citizens as well as why they find these concepts significant. ${ }^{20}$ Nevertheless, Professor Cuéllar's caution that we still have much to learn certainly continues to hold true. With respect to our understanding of citizen perspectives on the desirability of different governance mechanisms from a use standpoint, it is especially true, since most of the existing research on distributive and procedural justice only focuses upon people's willingness to accept decisions resulting from legal procedures. ${ }^{21}$

Our purpose in this article is to advance understanding of how citizens perceive and value different types of government processes that are intended to encourage or facilitate citizen involvement. Our view is that, when dealing with government decision-making processes that seek to encourage citizen involvement, it is valuable to understand which types of processes citizens favor and, further, the particular features of processes that citizens believe are especially worthwhile. Our project, through what we refer to as an empirical governance approach, is intended to advance the state of knowledge in both areas. ${ }^{22}$

Part II of this Article describes the design of our project, particularly our focus on mechanisms for citizens to participate in governance in the environmental-enforcement arena. Part III summarizes the methodology we used in developing our questionnaire for citizens interested in this field of governance. Part IV focuses on the questionnaire respondents' views concerning different types of procedures available to citizens interested in participating in promoting environmental compliance. Part $\mathrm{V}$ addresses respondents' views concerning the different features of these mechanisms. Part VI focuses in particular on respondents' perspectives regarding two mechanisms available to citizens: citizen suits under the environmental laws, and the Commission for Environmental Cooperation's (CEC's) citizen submissions process. Part VII, among

19. TYLER ET AL., supra note 16 , at 75.

20. See, e.g., id. at 85,100 (suggesting that procedural justice may be even more important than distributive justice in some contexts).

21. Willingness to use a procedure and willingness to defer to an outcome from it are related, but different, issues. See generally John ThiBAut \& LAUREns WaLKer, Procedural JusticE: A PSYCHOLOGICAL ANALYSIS (1975) (examining both people's pre-procedure preferences concerning how their dispute should be resolved and their post-evaluations of the decisions reached). More recently, Tom R. Tyler et al., The Two Psychologies of Conflict Resolution: Differing Antecedents of Pre-Experience Choices and Post-Experience Evaluations, in 2 GROUP PROCESSES \& INTERGROUP RELATIONS 99-118 (1999), directly compared pre- and post-experience evaluations of procedures.

22. Commentators have identified a number of reasons why citizen involvement is, or may be, beneficial. One outstanding question concerns the potential relationship between the hoped-for benefits of participation and the nature of citizens' views about different process features. 
other things, concludes by offering a simplified matrix approach for designing suitable procedures when a goal is to engage citizens.

\section{Citizen PREFERENCES AND ORGANIZATIONAL DESIGN}

Our initial research project focused on citizen opportunities to participate in environmental enforcement and compliance efforts in the United States. ${ }^{23}$ We identified eleven types of opportunities for citizens in the United States to participate in environmental enforcement and compliance. $^{24}$ These opportunities ranged from mechanisms we anticipate are relatively common knowledge in the environmental field (e.g., citizen suit provisions that exist under the major environmental statutes) ${ }^{25}$ to mechanisms with which many citizens and others may have had little if any contact (e.g., the opportunity to file petitions with the Environmental Protection Agency (EPA) to withdraw a State's authorization to implement a regulatory program because of deficiencies in the State's enforcement performance). ${ }^{26}$

We asked respondents a series of questions about each of these opportunities for citizens to participate in governance to encourage compliance with the environmental laws. ${ }^{27}$ In the initial section of the questionnaire we asked for basic information about people's preferences for and overall levels of satisfaction with these extant mechanisms available to citizens. For example, we asked respondents to rank the

23. Author David Markell presented this effort during the Fall 2006 International Union for the Conservation of Nature (IUCN) conference held at Pace Law School and also discussed it during an August 2007 meeting of the Organization of American States Sustainable Development Environmental Law Advisory Group. Several NGOs, professors, and others expressed interest in our pursuing similar work concerning enforcement practices in a significant number of other countries. Our plan at this point is to explore these opportunities following completion of this initial study of practices in the United States. Further, we are currently undertaking a similar study involving citizen participation processes in the land use arena, with a particular focus on growth management.

24. See infra appended Tables 1-2.

25. Citizen suit provisions have been included in the major environmental statutes for more than thirty years since their inception in the early 1970s. They have been used frequently during that period. For example, in a 2003 article, Professor Jim May indicates that since 1995, citizens have submitted more than 4500 notices of intent to file citizen suits and, on average, have filed about one lawsuit per week. James R. May, Now More Than Ever: Trends in Environmental Citizen Suits, 10 WIDENER L. REV. 1, 4, 30 (2003). The citizen suit provisions for three of the major federal environmental regulatory statutes are set forth in Clean Water Act, 33 U.S.C. $\S 1365$ (2000); Resource Conservation and Recovery Act, 42 U.S.C. § 6972 (2000); and Clean Air Act, 42 U.S.C. § 7604 (2000).

26. See, e.g., 40 C.F.R. $\S \S 271.22-.23$ (2007) (authorizing citizens to file such petitions for withdrawal of State RCRA authorization). Far fewer such petitions have been filed.

27. See infra appended Tables 1-4. See infra Part III for a summary of our methodology. 
eleven mechanisms in order of preference. ${ }^{28}$ In addition, we asked them to assign a value to the opportunities in an absolute sense-in terms of how helpful any of the opportunities are likely to be in enabling respondents to achieve their goals. Our goal in this section of the questionnaire was to understand respondents' preferences for different procedures and to assess respondents' views concerning the likely efficacy of these procedures in helping them to achieve their goals.

In the next part of the questionnaire, we sought to unpack the reasons why citizens favor one type of opportunity to participate in enforcement or compliance work over another. Based in part on the procedural and distributive justice literature, ${ }^{29}$ we identified twenty-two features of decision-making processes and asked respondents about the importance of each such feature. Features included the opportunity to provide written comments to decision makers, the availability of funding support for participation, the neutrality of the decision-making entity, and several others. Different extant processes available to citizens in the enforcement arena included different combinations of these features. Here we sought to understand why a procedure is desirable.

In addition to asking citizens about their preferences for particular features of government decision-making processes in the abstract, we focused specific attention on two such processes in the environmental enforcement arena: citizen suits available under the environmental laws against alleged violators, ${ }^{30}$ and the CEC's citizen submissions process, which allows citizens in the United States to file complaints in which they allege the government is failing to effectively enforce one or more environmental laws. ${ }^{31}$ Viewed through the lens of the procedural and

28. As part of this inquiry, we ask whether a respondent is familiar with each mechanism, to develop a sense of the role of familiarity in forming preferences.

29. E.g., Tyler, What is Procedural Justice?, supra note 18, at 103-35.

30. See, e.g., Clean Water Act $\S 1365(\mathrm{a})(1)$; Clean Air Act $\S$ 7604(a)(1), (3); Resource Conservation and Recovery Act $\$$ 6972(a)(1).

31. North American Agreement on Environmental Cooperation, U.S.-Can.-Mex., art. XIV, 1993, http://www.cec.org/pubs_info_resources/law_treat_agree/naaec/index.cfm?varlan=english (last visited Oct. 3, 2008) [hereinafter NAAEC]. For an overview of the CEC citizen submissions process, see, for example, David L. Markell, The Commission for Environmental Cooperation's Citizen Submission Process, 12 GeO. INT'L ENVTL. L. ReV. 545 (2000) [hereinafter Markell, Commission for Environmental Cooperation]. For a broader review of the CEC, see GREENING NAFTA: THE NORTH AMERICAN COMMISSION FOR ENVIRONMENTAL COOPERATION 256-57 (David L. Markell \& John H. Knox eds., 2003) and specifically David L. Markell, The CEC Citizen Submissions Process: On or Off Course?, in GREENING NAFTA, supra, at 274-98. See also John H. Knox, A New Approach to Compliance with International Environmental Law: The Submissions Procedure of the NAFTA Environmental Commission, 28 ECOLOGY L.Q. 1, 32 (2001); David L. Markell, Governance of International Institutions: A Review of the North American Commission for Environmental Cooperation's Citizen Submissions Process, 30 N.C. J. INT'L L. \& COM. REG. 759 (2005) [hereinafter Markell, Governance of International Institutions]. 
distributive justice literatures, it is clear these procedures vary significantly, as explained below.

Citizen suits are probably the best known vehicle for citizens to participate in environmental enforcement and compliance work. ${ }^{32}$ Each of the major environmental regulatory statutes creates a cause of action for citizens, ${ }^{33}$ allowing citizens with standing to bring suit in federal district court and claim a regulated party is operating in violation of one or more federal environmental laws. ${ }^{34}$ Citizens have extensive rights of participation in such cases. They may pursue discovery in order to develop a better understanding of regulated party and government regulators' performance. ${ }^{35}$ They may also participate actively in the trial phase of litigation by offering witnesses, cross-examining hostile witnesses, and engaging in the other features of conventional trial practice. $^{36}$ Further, citizens may seek wide-ranging relief, including punitive civil sanctions that can amount to as much as $\$ 32,500$ per day per violation for each day a violation continues, ${ }^{37}$ remedial relief to require a violator to cease its violations and, in some cases, to repair injury it has caused. ${ }^{38}$ Another key feature of citizen suit mechanisms in the federal environmental laws is that substantially prevailing citizens may recover attorneys' fees. ${ }^{39}$

The CEC's citizen submissions process is a much more recent addition to the menu of citizens' options for influencing environmental enforcement. Its features differ significantly from the citizen suit

32. A significant amount of scholarship exists on citizen suits. See, e.g., Symposium, Environmental Citizen Suits at Thirtysomething: A Celebration \& Summit, Part I, 10 WIDENER L. REV. 1 (2003); Symposium, Citizen Suits and the Future of Standing in the 21st Century: From Lujan to Laidlaw and Beyond, 12 DuKE ENVTL. L. \& POL'Y F. 1 (2001).

33. See supra note 30.

34. The elements of such causes of action vary depending on the statute. See Gwaltney of Smithfield, Ltd. v. Chesapeake Bay Found., Inc., 484 U.S. 49, 64-65 (1987) (holding that a citizen must make a good faith allegation that a party is operating in violation of the Clean Water Act and comparing the Act's jurisdictional requirement with the more flexible requirement in RCRA).

35. See generally FED. R. CIV. P. 26-37 (rules concerning discovery).

36. See id. at $38-53$.

37. 40 C.F.R. $\S 19.4$, tbl. 1 (2007). Penalties in citizen suits go to the U.S. Treasury. See, e.g., Steel Co. v. Citizens for a Better Env't, 523 U.S. 83, 106 (1998).

38. See David Markell, Is There a Possible Role for Regulatory Enforcement in the Effort to Value, Protect, and Restore Ecosystem Services?, 22 J. LAND UsE \& ENVTL. L. 549, 554, 558, 572 74 (2007).

39. The test for recovering attorneys' fees depends on the statute. See Buckhannon Bd. \& Care Home, Inc. v. W. Va. Dep't of Health \& Human Res., 532 U.S. 598, 602-03 (2001) (discussing the "American Rule" and the "catalyst theory"); see also Amigos Bravos v. EPA, 324 F.3d 1166, 1168 (10th Cir. 2003) (discussing the "catalyst theory" under the Clean Water Act); Sierra Club v. EPA, 322 F.3d 718, 719 (D.C. Cir. 2003) (discussing recovery of attorneys' fees under the Clean Air Act); Loggerhead Turtle v. County Council of Volusia County, 307 F.3d 1318, 1322 (11th Cir. 2002) (discussing fee-shifting provisions under the Endangered Species Act). 
mechanism summarized in the preceding paragraph. Citizen access to this mechanism is intended to be easier than citizen access to initiate a citizen suit in the courts. Standing, for example, is not supposed to be a significant hurdle to citizen participation in the CEC process. ${ }^{40}$ Further, the CEC process is intended to allow citizens to raise concerns about environmental enforcement without having to invest significant resources of the sort sometimes needed to press litigation. Rather than emulate the civil litigation's discovery and litigation process - which can be quite time-consuming and expensive for citizens - the CEC citizen submissions process invests the CEC Secretariat with responsibility for administration of the process after a citizen complaint is filed. ${ }^{41}$ The Secretariat administers its own investigative and fact-gathering process to pursue citizen concerns about non-compliance and ineffectual enforcement practices. ${ }^{42}$ The trade off for citizens is that in some respects the CEC process provides much more limited opportunities for participation than traditional civil litigation. Citizens have little, if any, ability to confront or obtain information from the offending entity whose activities citizens believe are flawed. ${ }^{43}$ Similarly, citizens' rights to interact with the "decision maker" (in this process, the CEC Secretariat and the CEC Council, depending on the stage of the process) are much more limited than in civil litigation. ${ }^{44}$

Similarly, the possible outcomes of the CEC process differ significantly from possible outcomes of citizen suits. For the former, the end result is the "reflexive" approach of spotlighting perceived inadequate performance with the hope that the attention will motivate improvements. ${ }^{45}$ Penalties and injunctive relief are not available under

40. The CEC is prepared to consider submissions from citizens without first requiring that citizens demonstrate harm of the sort that may be required for initiation of a citizen suit. On the other hand, there are limitations in the CEC process that do not exist in the citizen suit arena. See, e.g., NAAEC, supra note 31, art. 14(3)(a)(ii); see also Markell, Understanding Citizen Perspectives, supra note 14 , at $654-55$.

41. See generally NAAEC, supra note 31 , art. 14 (outlining the citizen submission process).

42. See id. art. 15(4).

43. There is no opportunity for any form of discovery. Markell, Understanding Citizen Perspectives, supra note 14, at 686 . Thus, FOIA is the primary tool available to citizens to obtain information. See generally The Freedom of Information Act, 5 U.S.C. $\S 552$ (2006).

44. Markell, Commission for Environmental Cooperation, supra note 31, at 550-63. For example, there is no opportunity for hearings. Id. at 562-63.

45. A. Dan Tarlock \& John E. Thorson, Coordinating Land and Water Use in the San Pedro River Basin: What Role for the CEO?, in GREENING NAFTA, supra note 31, at 217, 231 (discussing "reflexive approaches"); see also Eric Orts, Reflexive Environmental Law, 89 Nw. U. L. REV. 1227, 1278 (1995) (discussing how the EPA's "new policy's emphasis on 'self-policing' and 'selfdisclosure' fits with an emerging model of reflexive environmental regulation"). 
the CEC process. ${ }^{46}$ Finally, while the CEC Secretariat is intended to do much of the "heavy lifting" in investigating citizen complaints, there is no provision for attorneys' fees or other support for citizen engagement in the process. ${ }^{47}$

In sum, the citizen suits available under the major federal environmental laws and the citizen submission process created under the North American Free Trade Agreement (NAFTA) environmental side agreement represent very different approaches to engaging citizens in environmental enforcement. Access to the CEC process differs significantly from access to traditional citizen suit mechanisms; the nature of the processes and opportunities for financial assistance differ significantly, and the end results vary dramatically.

In theory, one procedure is intended to be a "traditional" adversary process in which citizens are actively involved throughout, operating before an independent tribunal with considerable authority to engage in fact-finding, authorize fact-finding by citizens, and impose appropriate relief. The other is intended to be more of a cooperative process in which citizens operate in a "fire alarm" capacity, and which circumscribes the tribunal's authority to facilitate and conduct factfinding or to impose relief. ${ }^{48}$

There is already a considerable body of commentary about these mechanisms. With respect to citizen suits, for example, scholars and others have opined at great length about the efficacy of such suits, and the importance of different features. ${ }^{49}$ Concerns about gaining access to the courts to raise concerns have been a recurring theme. ${ }^{50}$ Another significant issue has been the costs of litigation and the possibilities of recovering fees. ${ }^{51}$ Similarly, several commentators have written about

46. Rather, NAAEC Article 15 merely provides for the development and possible publication of a factual record. See NAAEC, supra note 31, art. 15(2).

47. See generally id. arts. 14-15 (regarding submissions on enforcement matters and factual records).

48. Kal Raustiala, Citizen Submissions and Treaty Review in the NAAEC, in GREENING NAFTA, supra note 31, at 256, 264 (discussing "fire alarms"). Substantively, the focus of the two processes differs as well. Citizen suits tend to focus on particular violations, while the CEC process potentially has a broader scope. See Markell, Governance of International Institutions, supra note 31, at 791. Further, while citizen suits focus on alleged violator activity, the CEC process focuses on government enforcement performance. See Markell, Understanding Citizen Perspectives, supra note 14 , at 662 .

49. See, e.g., Jim Hecker, The Difficulty of Citizen Enforcement of the Clean Air Act, 10 WidENER L. REV. 303, 304-05 (2004); Patrick Parenteau, Citizen Suits Under the Endangered Species Act: Survival of the Fittest, 10 WIDENER L. REV. 321, 322 (2004).

50. See, e.g., Albert C. Lin, The Unifying Role of Harm in Environmental Law, 2006 WIS. L. REV. 897, 915 (2006).

51. See, e.g., Robert L. Glicksman et Al., EnVironmental Protection: LaW AND Policy 
the effectiveness of the CEC citizen submissions process and about the key features that account for its success (or lack thereof). ${ }^{52}$ Citizens have raised concerns about the lack of transparency in the process, for example. ${ }^{53}$ Another concern is that the "playing field" has not been level because the CEC Council, which exercises an integral role in implementing the process, has not been neutral in performing its responsibilities. ${ }^{54}$ Other concerns have been raised about the quantity and quality of opportunities for citizens to participate in the process, and about the adequacy of the remedial side of the process. ${ }^{55}$

Our empirical governance approach is intended to build on, and begin to test, the extant literature on enforcement mechanisms that allow for citizen involvement, including citizen suits and the CEC's citizen submissions process. In particular, the project is intended to serve as a model for how to develop empirical information about at least two issues: (1) the nature of citizen preferences for different types of opportunities to participate in environmental enforcement and compliance-related activities, and (2) the reasons why citizens prefer some mechanisms to others - in particular, the value citizens attach to specific features of participation opportunities. More generally, as noted above, our argument is that many areas of the legal system could potentially benefit from the development of a framework through which publicly desirable procedures could be designed. It is often the case that, for example, irrespective of whether we are discussing environmental conflicts or disputes in small claims court, the public is resistant to participating in governance or in deferring to the decisions governance institutions make. We would benefit in such settings from better information about what dispute resolution processes are desirable in the

1037 n.8 (5th ed. 2007).

52. Randy Christensen, The Citizen Submission Process Under NAFTA: Observations after 10 Years, 14 J. ENVTL. L. \& PRAC. 165 (2004) (noting that the citizen submission process has been an effective means of "highlighting environmental problems, compelling governments to engage in debates, and bringing about positive environmental change through independent factual investigations"); Markell, Understanding Citizen Perspectives, supra note 14, at 651 (2006); Gustavo Alanís Ortega, Public Participation within NAFTA's Environmental Agreement: The Mexican Experience, in LINKING TRADE, ENVIRONMENT, AND SOCIAL COHESION: NAFTA EXPERIENCES, Global Challenges 183-86 (John J. Kirton and Virginia W. Maclaren eds., 2002); Chris Wold et al., The Inadequacy of the Citizen Submission Process of Articles 14 \& 15 of the North American Agreement on Environmental Cooperation, 26 LOY. L.A. INT'L \& COMP. L. REV. 415, 416-17 (2004).

53. Markell, Understanding Citizen Perspectives, supra note 14, at 688-91.

54. Id.

55. Other mechanisms in addition to citizen suits and the CEC process have been the subject of commentary as well. See, e.g., Janet V. Siegel, Negotiating for Environmental Justice: Turning Polluters into "Good Neighbors" Through Collaborative Bargaining, 10 N.Y.U. ENVTL. L.J. 147, 180-88 (2002) (discussing Good Neighbor Agreements). 
eyes of both the disputants and the public more generally. We offer this initial article in order to share our objectives, to solicit feedback on the entire project, and, hopefully, to stimulate similar efforts to embrace the legal academy's call to greater recourse for empirical work in order to inform review and development of public policy. ${ }^{56}$

\section{METHODOLOGY}

A wide variety of people involved in environmental litigation were asked via e-mail to participate in this study by completing our questionnaire. ${ }^{57}$ Our target group was environmental activists because this is a group likely to be interested in participating in environmental enforcement by using one or more of the mechanisms we identified. ${ }^{58}$ We made a systematic effort to identify individuals (lawyers and clients) who had used the different mechanisms we listed. For citizen suits under the environmental laws, for example, we identified and tried to contact all plaintiffs and lawyers who between January 1, 2004, and March 13, 2006, filed citizen suits against alleged violators of the Clean Water Act, the Clean Air Act, and the Resource Conservation and Recovery Act, as well as those plaintiffs and lawyers who filed lawsuits against the government during that time period under one or more of these laws for alleged failure to effectively enforce the provisions of the statute(s) in question. $^{59}$ We identified and sought to contact all U.S. non-

56. The legal academy has highlighted the importance of empirical work as an important tool to a greater understanding of how society works and of how to refine it so that it works better. For example, the 2006 Association of American Law Schools (AALS) annual meeting focused on empirical scholarship. See Ass'n of Am. Law Sch. Annual Meeting, http://www.aals.org/am2006 theme.html (last visited Oct. 3, 2008).

57. We also contacted several individuals by telephone who had used one or more of the mechanisms we asked about.

58. Our choice of respondents highlights a broader question, notably, whose views are relevant to questions concerning governance structure? Is it the general public? Or is it the groups that are most likely to actually participate, e.g., activists? As noted in the text, in this initial effort we focused on environmental activists because we believed they were likely to participate in the procedures we identified and also because our focus in this project is on use of the government processes. For some purposes, investigating the views of broader population cross-sections is obviously appropriate. This issue is an important one for methodological design.

59. Two databases were used to conduct this search: (1) Westlaw and (2) Public Access to Court Electronic Records (PACER). PACER is an electronic service that allows users to search case and docket information from federal appellate, district, and bankruptcy courts, and from the U.S. Party/Case Index. Administrative Office of the U.S. Courts, What is PACER?, http://pacer.psc.uscourts.gov/pacerdesc.html (last visited Oct. 4, 2008). The PACER System offers electronic access to case dockets to retrieve information such as a listing of all parties and participants, the nature of the suit, and the types of documents filed for each case. Id. PACER has a list of codes that correspond to different types of lawsuits. Administrative Office of the U.S. Courts, PACER Frequently Asked Questions, http://pacer.psc.uscourts.gov/faq.html (last visited Oct. 4, 
governmental organizations (NGOs) and NGO attorneys that have filed submissions with the CEC process. ${ }^{60}$ Similarly, through a Freedom of Information Act (FOIA) request to EPA we obtained a list of all entities that have filed petitions to withdraw state authorization. We sought to contact each of these. ${ }^{61}$

To participate in the study, respondents logged into a web-based survey site $^{62}$ and completed a questionnaire. We received thirty responses. To learn more about our respondents, we asked them to classify themselves in two ways. First, they indicated their political party affiliation, ranging from strongly Republican (7) to strongly Democratic (1). ${ }^{63}$ The mean was 2.08, suggesting that most respondents

2008). Suits primarily concerned with environmental issues are tagged with code 893 . Administrative Office of the U.S. Courts, PACER Nature of Suit Glossary, http://pacer.psc.uscourts.gov/natsuit.html (last visited Oct. 4, 2008). A search was conducted for all civil suits filed between January 1, 2004, and March 13, 2006, that had code 893. This returned over 1000 cases. Because PACER does not have the capability to further restrict the search, the docket for each case was viewed and the first complaint downloaded to ascertain whether the suit was filed pursuant to one of the statutes in question.

A search on Westlaw was also conducted. Westlaw allows for the input of search terms as a means to restrict the results returned in a docket and/or pleadings search. The search terms used were: "33 U.S.C. 1365(a)(1)" "42 U.S.C. 7604(a)(1)" "42 U.S.C. 6972(a)(1)" "42 U.S.C. 7604(a)(3)" "42 U.S.C. 7604(a)(2)" "33 U.S.C. 1365(a)(2)" and "42 U.S.C. 6972(a)(2)." These are the citations for the citizen suit provisions of the statutes in question. Because Westlaw allowed for the use of more restrictive search terms, the citizen suit information was compiled using this database. After we completed this part of the task, we again consulted PACER to locate any civil suits meeting the search criteria that could not be found on Westlaw.

The mailing address and e-mail address for each attorney were located on Westlaw or PACER if available in those databases. For each attorney who did not have an e-mail address available on Westlaw or PACER, a Google search was conducted to locate the Web site of the law firm or organization of those attorneys. If available, the e-mail address for the attorney was taken from the Web site. E-mail addresses for the plaintiffs were not available on either Westlaw or PACER. A Google search was conducted to locate the Web site of each institutional or organizational plaintiff. If available, the e-mail address for each institution or organization was taken from the Web site. No search was conducted for plaintiffs listed as individuals.

Not all courts make their information available for the PACER U.S. Party/Case Index. Additionally, not all of the cases had pleadings that were available for viewing on either Westlaw or PACER. These two circumstances placed limitations on the number of citizen suits from which the plaintiff and attorney information could be drawn.

60. We obtained this information from www.cec.org, the CEC Web site.

61. For a list of these entities, see Letter from Marilyn J. Kuray, Attorney-Advisor, Office of Gen. Counsel, Cross-Cutting Issues Law Office, U.S. Envtl. Prot. Agency, to David Markell (Mar. 29,2005 ), at $1-16$ (on file with authors). In addition to these specific groups, we sought to reach all of the law school environmental clinics who represent public interest groups by sending an e-mail to members of the clinic listserve notifying them of the survey and requesting they complete it. We also contacted representatives of several national environmental groups (National Resources Defense Counsel, the Sierra Club, etc.) and requested that they complete the survey and notify their colleagues of the opportunity to do so.

62. We used the Create Survey Web site, http://www.createsurvey.com (last visited Oct. 4, 2008)

63. David Markell \& Tom R. Tyler, Survey, Stakeholder Input into Environmental Regulation (Dec. 19, 2006), http://www.createsurvey.com/cgi-bin/pollfrm?s=36069\&m=zaclZV (last visited 
were Democratic. ${ }^{64}$ An examination of the responses showed $89 \%$ of the respondents were Democratic, $12 \%$ moderate. ${ }^{65}$ Similarly, respondents classified themselves as extremely conservative (7) to extremely liberal (1). ${ }^{66}$ The mean was 2.41 , with $78 \%$ of respondents indicating they were liberal, $18 \%$ indicating they were moderate, and $4 \%$ indicating they were conservative. $^{67}$

The questionnaire also included an eight-item trust-in-government scale. The items were: "You can usually trust the government to do what is right"; "You are generally satisfied with the actions of the government in the area of environmental regulation"; "You feel that the government is run for the benefit of all the people"; "If you took a complaint over environmental policy to the government, your views would be given attention"; "People like yourself have considerable influence over government decisions about environmental policy"; "There is not much about our government that you feel proud of (reverse scored)"; "The government is too strongly influenced by special interests looking out for themselves (reverse scored)"; and "You are often frustrated by the actions of government agencies (reverse scored)." ${ }^{, 68}$ The item responses ranged from disagree strongly (1) to agree strongly (6). ${ }^{69}$ The overall scale scores ranged from one to six, with high scores indicating a high level of trust. The mean was 2.44 (standard deviation $=0.77$; alpha $=$ 0.83 ), reflecting limited trust and confidence in government. ${ }^{70}$

Respondents also indicated their confidence in social institutions on a scale ranging from low confidence (1) to high confidence (6). They first indicated their confidence in the people running eight institutions: the American business community, the executive branch, the press, the Supreme Court, the Congress, regulatory agencies of the government, non-governmental agencies, and state governments. ${ }^{71}$ They then rated how frequently leaders of these same institutions try to do what is right

Sept. 9, 2008) [hereinafter Survey].

64. Stakeholder Input into Environmental Regulation: Survey Results (2007) (on file with authors) [hereinafter Survey Results].

65. Id.

66. See Survey, supra note 63.

67. See Survey Results, supra note 64.

68. See Survey, supra note 63.

69. Id.

70. See Survey Results, supra note 64. Coefficient alpha is a term used by psychologists to refer to the degree to which the items in a scale belong together. Essentially, it reflects the average intercorrelation among items. Higher numbers indicate higher intercorrelation and a better scale. Numbers above 0.80 are excellent and numbers above 0.60 are reasonable. See N.C. State Univ., Scales and Standard Measures, http://www2.chass.ncsu.edu/garson/PA765/standard.htm (last visited Oct. 4, 2008).

71. See Survey, supra note 63. 
for all the people in their communities, using a scale ranging from never (1) to always (6). ${ }^{72}$ The mean for the sixteen-item scale was 3.11 $($ standard deviation $=0.61$; alpha $=0.85)$. ${ }^{73}$ Respondents had much more confidence in the people running NGOs than was the case for other institutions.

We also asked respondents how important they think it is to have a procedure available in situations involving violations of the environmental laws so that people can use it $(1=$ very unimportant; $6=$ very important). ${ }^{74}$ The results of this analysis are shown in appended Table $1 .{ }^{75}$ Respondents indicated that all of the mechanisms we listed should be available and that people are most likely to believe traditional legal mechanisms should be available. ${ }^{76}$ Those include the ability to file a citizen lawsuit (mean $=5.89$ ), to file a citizen suit against the government $($ mean $=5.74)$, and to file a common law action $($ mean $=$ $5.42) .^{77}$

In short, this set of responses allows us to begin examining preferences among those who are likely to initiate or participate in environmental enforcement litigation or other similar actionsenvironmental activists and the attorneys who represent them. Overall, these results indicate that those completing the questionnaire are generally Democratic and liberal, having low levels of trust and confidence in government and other social institutions; the marked exception being NGOs (the mean trust in NGOs was 3.93, versus an average of 2.90 for other institutions on a scale ranging from 1 to 6 , with high scores indicating more trust). ${ }^{78}$ Further, they strongly support a legal system that affords citizens significant opportunities to participate in promoting compliance with the environmental laws. ${ }^{79}$

It is obviously possible that a random cross-section of the population would have provided very different responses if we had targeted such a group. Our findings should be considered with this limitation in mind. Thus, for example, a policy maker interested in designing a process

72. Id.

73. See Survey Results, supra note 64.

74. See Survey, supra note 63.

75. See infra appended Table 1. In appended Table 1, a scale of 1 to 6 is used. Each respondent is asked to rate the desirability of having each of the eleven procedures available for people to use.

76. Id.

77. Id.

78. See Survey Results, supra note 64.

79. Id. 
intended to appeal to the general population might well use a different methodology to select questionnaire recipients. ${ }^{80}$

Further, even among Environmental NGOs, it has been theorized that the type of organization in which a person works may influence that person's views concerning different issues. For example, a group's funding sources may be very relevant to its views concerning the importance of an attorneys' fees recovery provision in a participation process. $^{81}$ A follow-up, expanded research effort would seek to obtain more nuanced information of this sort.

\section{What Procedures Do People SAy They Are LiKely to USE to RESOLVE ENVIRONMENTAL DISPUTES?}

People completing the questionnaire were asked to indicate their likelihood of using each of eleven procedures to resolve two types of environmental disputes. The first type of dispute is one in which "a single party is violating its environmental obligations." 82 The second type of dispute involves a situation in which "widespread violations are occurring at many locations and are being committed by many individuals or companies, e.g., several companies are violating their Clean Water Act permitting obligations." 83

These procedures are as follows:

(1) File a citizen suit against the violator based upon statutory law.

(2) Participate in a government enforcement action.

(3) File a common law cause of action.

(4) File a submission with the CEC.

(5) File a citizen suit against the government.

(6) Raise concerns with the EPA's Office of Inspector General.

(7) Petition the EPA to withdraw state authorization.

(8) Informal contact with the violator.

80. See supra note 58. The idea that a procedure should be acceptable to people irrespective of ideology, ethnicity, or other characteristics, (e.g., wealth), has been articulated in the literature on dispute resolution. See, e.g., E. Allan Lind, Yuen J. Huo \& Tom R. Tyler, ... And Justice for All: Ethnicity, Gender, and Preferences for Dispute Resolution Procedures, 18 LAW \& HuM. BEHAV. 269 (1994); Tom R. Tyler, Governing Amid Diversity: The Effect of Fair Decisionmaking Procedures on the Legitimacy of Government, 28 LAW \& SoC'Y REV. 809 (1994); Tom R. Tyler, Multiculturalism and the Willingness of Citizens to Defer to Law and to Legal Authorities, 25 LAW \& SOC. INQUIRY 983 (2000).

81. See, e.g., Mark Seidenfeld, Empowering Stakeholders: Limits on Collaboration as the Basis for Flexible Regulation, 41 WM. \& MARY L. REV. 411 (2000).

82. See Survey, supra note 63.

83. Id. 
(9) Informal contact with the government.

(10) Pursue shaming opportunities, such as notifying the media.

(11) Take some other type of action. ${ }^{84}$

\section{A. Results}

Appended Table 2 indicates the likelihood that respondents think they would use any of these eleven procedures. ${ }^{85}$ In the case of an individual violation, the primary procedure respondents indicated they would use is filing a citizen lawsuit (mean $=4.93) .{ }^{86}$ With widespread violations, respondents indicated they would be most likely to use shaming mechanisms $($ mean $=4.39) .{ }^{87}$ These initial findings suggest that respondents generally view lawsuits as the key mechanism they would use to respond to wrongdoing in single violation situations. In contrast, they are more likely to pursue a shaming opportunity and less likely to file a lawsuit in the widespread violation context. ${ }^{88}$

A second question respondents were asked is whether any of the actions identified would allow them to achieve their goals in the situation. Respondents were given a six-point scale on which they noted the likelihood that at least one of the actions listed would allow them to achieve their goals (very unlikely; unlikely; somewhat unlikely; somewhat likely; likely; very likely). ${ }^{89}$ Responses were collapsed into two groups: likely and unlikely. In the case of the single violator, $71 \%$ indicated at least one was likely to be effective. ${ }^{90}$ With multiple violators, $68 \%$ indicated at least one was likely to be effective. ${ }^{91}$

\section{B. Implications}

It is interesting that respondents identified different process preferences depending on the nature of the non-compliance involved.

84. See infra appended Table 1.

85. See infra appended Table 2. Appended Table 1, infra, shows the eleven procedures outlined. For each procedure, respondents were asked whether they were familiar with it. See Survey, supra note 63. Among those who said "yes," the average likelihood of using each procedure is determined separately for single and widespread violations. Higher numbers indicate a greater likelihood of using the procedure.

86. See infra appended Table 2 .

87. Id.

88. Id.

89. See Survey, supra note 63

90. See Survey Results, supra note 64.

91. Id. 
Respondents were more likely to view citizen litigation as desirable for single violations. ${ }^{92}$ With widespread violations, people preferred going outside the legal system and using shaming mechanisms. ${ }^{93}$

Further research would be useful to determine why citizen activists may prefer different mechanisms depending on the context. We speculate that at least part of the answer may be that respondents are more confident in the likely efficacy of citizen lawsuits in the single violator situation than in the multiple violator context. But, it would be worth further investigation to assess whether the difference is based primarily or entirely on concerns related to distributive justice (e.g., the likelihood of "success" anticipated in using different mechanisms in different contexts) or whether procedural justice issues play a role in the differing preferences as well. Further, if procedural justice issues are relevant, there is the question of which aspects of procedural justice are most salient. ${ }^{94}$ As we point out infra,${ }^{95}$ we found through other questions that procedural justice features vary in their salience to citizens depending on the process involved.

Similarly, our findings raise a question concerning the role of familiarity in shaping the respondents' preferences. Approximately $80 \%$ of those who completed the questionnaire indicated they are familiar with the traditional legal mechanism of the lawsuit because they have personally been involved in using that procedure in the past, and suggest they would respond to a legal problem by using that mechanism in the future. ${ }^{96}$ They are less accustomed to using other procedures, such as the CEC procedure. ${ }^{97}$ In fact, almost none of the respondents had any personal experience with the CEC procedure, which is not surprising given that it is a new and not widely used procedure. ${ }^{98}$ One possible explanation for the relative popularity of citizen suits that is consistent with our findings is that people prefer procedures with which they have personal experience. ${ }^{99}$ More research would be needed to test the role of

92. See infra appended Table 2 .

93. Id.

94. See infra Part VI.

95. Id.

96. See Survey Results, supra note 64.

97. Id.

98. Id.

99. Considerable research in psychology supports the argument that people are more likely to like those aspects of social situations with which they are familiar. See, e.g., Robert B. Zajonc, Attitudinal Effects of Mere Exposure, 9 J. PERSONALITY \& SOC. PSYCHOL. MONOGRAPH SuPP., pt. 2, 1 (1968) (offering a hypothesis that repeated exposure to a stimulus object enhances an individual's attitude toward it). Familiarity is obviously not necessarily the only reason lawsuits are preferred. More work, along the lines discussed in Parts V and VI, will help shed light on the role of familiarity 
familiarity in respondents' preferences among the procedures we identified.

Also of interest are the findings concerning expectations of effectiveness of any of the processes in the two situations we studied. The suggestion that citizens may be less sanguine about the likely efficacy of existing legal or other mechanisms to address situations involving multiple violators seemingly raises questions about the efficacy of such mechanisms to deal with potentially larger noncompliance situations - for example, whether there is a gap, unintended or not, in our legal mechanisms for addressing non-compliance. ${ }^{100}$

Somewhat related, approximately $30 \%$ of those interviewed do not think any of the existing mechanisms will enable them to achieve their goals. ${ }^{101}$ This suggests more research is needed regarding their normative and other goals and the relationship of those goals to societal interests and priorities. In this study, we did not ask people what their goals were, only whether they could achieve them within the existing structure.

\section{What Are the Features of a Desirable Procedure?}

The ratings indicate that respondents varied in the degree in which they regarded different procedures as being procedures they would use and/or as procedures they felt should be available for others to use. We were interested in understanding why respondents made these desirability ratings.

To examine why procedures were viewed as desirable, we asked respondents to indicate how important different procedural features were to the desirability of those procedures. The scale used was (1) very unimportant to (6) very important. Ratings for seventeen attributes are presented in appended Table 3. ${ }^{102}$ Those attributes are grouped into six

compared to other factors. We asked respondents about their overall familiarity with the processes we were studying in the specific context of each of the fact patterns we were asking about. Thus, it is possible that respondents' greater familiarity with lawsuits in the individual violator situation may have affected their preferences.

100. In addition to questions concerning the utility or efficacy of extant legal mechanisms in addressing non-compliance in different situations, questions exist concerning optimal levels of compliance and enforcement. See, e.g., David L. Markell, The Role of Deterrence-Based Enforcement in a "Reinvented" State/Federal Relationship: The Divide Between Theory and Reality, 24 HARV. ENVTL. L. REV. 1, 2-4 (2000). Similarly, there are questions regarding optimal availability of lawsuits and other mechanisms in light of different goals and contextual realities, such as enhancing legitimacy and resource constraints.

101. See Survey Results, supra note 64.

102. See infra appended Table 3. People were asked about twenty-two attributes, seventeen of which fit into traditional procedural justice categories. Appended Table 3 shows two types of 
procedural clusters: overall procedural justice, neutrality, trust, respect, voice, and control over the outcome. ${ }^{103}$ Overall average scores are presented for the clusters. ${ }^{104}$

\section{A. Results}

One reason people might view a procedure as desirable is that it allows them to achieve their outcome goals. Respondents indicated that the ability to achieve their outcome goals was one important aspect of a procedure (mean $=5.51) .{ }^{105}$ In particular, people wanted to have an opportunity to change behavior they objected to $($ mean $=5.71) .{ }^{106}$

Interestingly, people also valued other elements of procedures besides the outcome they would deliver. In particular, people put weight on having neutral procedures $($ mean $=5.58) .{ }^{107}$ This included procedures that would lead to factually-based decisions (mean $=5.88$ ); procedures that would lead to legally appropriate outcomes (mean $=5.64$ ); procedures that allowed appeals (mean $=5.43$ ); and procedures that consistently applied laws to particular legal problems $($ mean $=5.39) .{ }^{108}$

They also valued evidence that decision makers are trustworthy. Authorities are viewed as more trustworthy when they give adequate attention to the concerns of those who appear before them and when they explain the reasoning behind their decisions. Respondents indicated adequate consideration of their concerns was especially important (mean $=5.33)^{109}$

results. First, scales were constructed to represent ideas. Those scales combine the items listed below them. The mean desirability of each idea is reflected in the average for that scale, with higher numbers indicating more desirability. The desirability of each item is also shown, using the same scale. So, for example, the mean desirability of neutrality is 5.58 , while the mean desirability for a decision based on facts, one of the five items that make up the neutrality scale, is 5.88. See id.

103. See infra appended Table 3. "Overall procedural justice" means that people were simply asked whether the procedure is just. The other four categories ask about procedural dimensions often associated with procedural justice. Past studies have suggested that the four categories explain about $80 \%$ of the variance in overall procedural justice judgments. See TOM R. TYLER \& YUEN J. Huo, Trust in the Law: Encouraging Public CoOperation with the Police and Courts 7696 (2002).

104. See infra appended Table 3.

105. Id.

106. Id

107. Id.

108. Id.

109. Id. 


\section{B. Implications}

These findings support the traditional procedural justice finding that people care about more than just winning their case. The finding that the likely outcome of a procedure shapes its desirability follows naturally from the suggestion that people approach wrongdoing with the motivation to end behavior they view as inappropriate and illegal. However, the ability to successfully bridge across different views concerning conduct in a given setting depends upon people being willing to use or participate in processes in which they do not control the outcome (and cannot be assured that the outcome will be favorable). ${ }^{110}$

In this setting, as in earlier research on procedural justice, people recognized the importance of concerns beyond their own self-interest. In fact, people rated having a neutral forum as being the most important feature of a procedure $($ mean $=5.58) .{ }^{111}$ A neutral forum is one that leads to a fact-based (mean $=5.88)$ and lawful (mean $=5.64)$ outcome. ${ }^{112}$ It is not simply a procedure that allows the party to prevail and achieve the outcome it wants.

The respondents also rated having a trustworthy authority as the decision maker as important to their concern with prevailing and achieving their desired outcome when they are evaluating a procedure's desirability (mean $=5.16) .{ }^{113}$ A trustworthy authority is an authority who considers the concerns of the parties when deciding $($ mean $=5.33)$ and who explains the reasons for the decision after making it (mean $=$ 4.96). ${ }^{114}$ Again, these concerns reflect procedural concerns that may relate to, but appear to be distinct from, winning. ${ }^{115}$

Overall, these findings suggest that respondents recognized the value of using procedures that have the characteristics of a just procedure-in

110. As one of us has pointed out elsewhere, this is important to citizens' willingness to defer to the outcomes of processes as well as to their willingness to participate in them. See Tyler, What is Procedural Justice?, supra note 18, at 104 (defining "procedural justice").

111. See infra appended Table 3 .

112. Id.

113. Id.

114. Id.

115. Trust is correlated with control $(\mathrm{r}=0.22$, n.s.), suggesting that people believe they are more likely to achieve desired outcomes when they have a trustworthy authority. David L. Markell \& Tom R. Tyler, Analysis (data on file with authors). Similarly, people are more likely to believe they will achieve desired outcomes in a neutral procedure $(\mathrm{r}=0.36, \mathrm{n} . \mathrm{s}$.). Id. In general, people believe they are more likely to achieve desired outcomes when the procedure is fair $(\mathrm{r}=0.38, \rho<0.05)$. Id. On the other hand, people can see the difference between a procedure that is likely to lead to a desirable outcome and a procedure that is fair. Id. 
particular, neutrality and a trustworthy decision maker. This suggests openness to participating in a process because it is a fair one. ${ }^{116}$

\section{Why ARE Citizen SUITS AND THE CEC CiTIZEN SUBMisSIONS PROCESS DESIRABLE?}

The previously outlined findings are based upon people's views on what they believe leads a procedure to be desirable to them. An alternative approach to addressing this question is to correlate the existence of procedural features with desirability ratings, inferring that people find a feature desirable when the desirability of a procedure is linked to whether or not it has that feature. This approach was applied to two procedures: citizen lawsuits and the CEC procedure. ${ }^{117}$

Desirability was assessed for single actors and for large-scale wrongdoing. The single-actor scale and the large-scale-wrongdoing scales each had the same seven items: "You would be satisfied with this mechanism as a way to respond"; "Using this mechanism would be a good way to respond to a violation"; "You would be very willing to use this mechanism"; "You would generally favor using this mechanism"; "Having this mechanism available allows citizens to play an appropriately strong role in promoting compliance with the law"; "This mechanism gives citizens a meaningful way to shape environmental law"; and "This mechanism gives citizens a meaningful way to shape the regulatory actions of government."118 Both scales were reliable for citizen suits and for the CEC submissions process, with the former more reliable than the latter. ${ }^{119}$

Several procedural attributes were assessed. First, overall procedural justice was measured by asking respondents whether the procedure was "generally . . . a fair procedure for handling your complaint." 120

Neutrality was assessed using five items: the procedure would "Lead to a decision based on facts"; "Lead to a decision reflecting a consistent application of the law"; "Provide adequate opportunities to appeal";

116. It also suggests openness to accepting the results of a decision because it is made fairly. As has been noted elsewhere, it is this willingness to defer to fair procedures that is central to the ability of the courts to manage contentious environmental disputes. See, e.g., E. Allan Lind \& TOM R. Tyler, The Social Psychology of Procedural Justice (1988) [hereinafter Lind \& Tyler, THE Social Psychology]; Tom R. Tyler, Why People Obey the LaW: Procedural Justice, LEGITIMACY, AND COMPLIANCE (2006); TYLER \& HUO, supra note 103.

117. See infra appended Table 4.

118. See Survey, supra note 63.

119. See infra appended Table 4; Survey Results, supra note 64; see also supra note 70.

120. See Survey, supra note 63. 
"Lead to appropriate application of the law to legal liability"; and "Lead to a decision fair to everyone involved." 121

Trust in authorities was measured using two items: the procedure would "Lead to a decision based on an adequate consideration of your concerns," and would "Lead to a decision in which the authorities adequately explained their reasons."

Respect was also measured using two items: the procedure would "Respect everyone's rights" and would "Treat those involved with dignity and courtesy."123

Voice was measured using four items. The items indicated that the procedure would "Provide an opportunity to present arguments in writing"; "Provide an opportunity to present arguments orally"; "Enable you to have a dialogue with the other party"; and "Enable you to have a dialogue with the decision maker." 124

Finally, control over outcomes was measured using three items: the procedure would "Give you some control over the outcome," would "Help you get the outcome you wanted," and would "Provide you a way to effectively change the behavior to which you object."125

\section{A. Results}

An intriguing finding about respondents' views concerning the desirability of citizen suits and the CEC citizen submission procedure is that the features in the citizen suit process that respondents valued are very different from the citizen submission features to which respondents gave highest value. ${ }^{126}$ As shown in appended Table 4, the key issue shaping desirability concerning the citizen submission procedure is the degree to which the procedure provides opportunities for voice $(\mathrm{r}=$ 0.58 ), followed by the extent to which people believe they will be treated

\footnotetext{
121. See infra appended Table 3; Survey, supra note 63.

122. See infra appended Table 3; Survey, supra note 63.

123. See infra appended Table 3; Survey, supra note 63.

124. See infra appended Table 3; Survey, supra note 63.

125. See infra appended Table 3; Survey, supra note 63.

126. An important qualification concerning the responses regarding the CEC procedure is that, while twenty-four of the thirty respondents indicated they have been involved in lawsuits, only two of the respondents have used the CEC procedure. This means the CEC procedure ratings are based upon indirect knowledge of the CEC procedure; namely, respondents' expectations about what will happen if they use the procedure or information from others who have used it. The lower reliabilities associated with evaluations of the CEC procedure reflect the lack of personal experience with the CEC procedure, and indicates that respondents have a less clearly formed understanding of this procedure. Having familiarity with a procedure allows people to make more coherent evaluations of its features.
} 
with courtesy and respect in the process $(r=0.48) .{ }^{127}$ In contrast, for the lawsuit procedure, neutrality and trust were the central procedural dimensions. ${ }^{128}$ In the case of both procedures, control over outcomes is important $(\mathrm{r}=0.42) .^{129}$

Interestingly, unlike the findings with lawsuits, overall procedural justice ratings for the citizen submission process are not strongly linked to desirability $(\mathrm{r}=0.28) .{ }^{130}$ In the case of lawsuits, these overall ratings were the strongest predictor of desirability $(\mathrm{r}=0.50) .{ }^{131}$ Why the difference? Additional research is needed to understand this response, including the relationship between overall procedural justice ratings and the desirability of a procedure. One possibility is that respondents associated procedural justice with neutrality - a feature of lawsuit desirability - and not with voice or respect. This raises the question of whether, when people think about the question of whether a procedure is just, they may be drawn to thinking about whether the procedure is factbased and rule-guided (i.e., neutral). Based upon legal training, or the legal framing of issues, people may not associate treatment with respect and dignity with the issue of whether a procedure is just or unjust. However, as we have noted, other research shows people do make that connection in practice. ${ }^{132}$ When treated disrespectfully, they say a procedure is unjust. ${ }^{133}$ Hence, it may be that our respondents' prior judgments about the procedural justice of traditional legal procedures emphasize elements of decision-making, rather than issues of interpersonal treatment. Again, further research is needed to explore this finding.

\section{B. Implications}

These findings are potentially important and warrant follow-up because, as indicated above, they suggest that respondents value different procedures for different reasons. What factors are linked to the

127. See infra appended Table 4 .

128. Id.

129. Id. As noted supra, citizens have little control over the outcome of the CEC process. Future research to elaborate on the importance of outcomes to the value of processes like the CEC procedure would be an important contribution. See, e.g., Markell, Understanding Citizen Perspectives, supra note 14.

130. See infra appended Table 4.

131. Id.

132. Steven L. Blader \& Tom R. Tyler, A Four-Component Model of Procedural Justice: Defining the Meaning of a "Fair" Process, 29 PERSONALITY AND SOC. PSYCHOL. BulL. 747-58 (2003) [hereinafter Blader \& Tyler, A Four-Component Model].

133. Id. 
desirability of lawsuits? The analyses shown in appended Table $4^{134}$ indicate that respondents prefer lawsuits to the degree their overall judgment is that the procedure is fair ("provide[s] a just procedure for handling your complaint") $(\mathrm{r}=0.50)$, they feel the procedure is neutral ( $\mathrm{r}$ $=0.50)$, the decision-making is trustworthy $(\mathrm{r}=0.45)$, and they have control over the outcome $(\mathrm{r}=0.49) .{ }^{135}$ As was the case with the hypothetical ratings of procedural desirability, respondents' evaluations of the acceptability of procedures suggest they are concerned about more than their own outcomes. ${ }^{136}$ Respondents, of course, want a procedure in which they will prevail. However, they want more than that. They also want a procedure that is fair. Thus, the respondents' views suggest that citizens are, other things being equal, seemingly more likely to participate in, or use, procedures they view to have these characteristics than procedures that do not.

It is also interesting that this perspective on lawsuits mirrors the traditional concerns of the legal system with the trial process through which lawsuits are often resolved. Discussions of the legal system focus upon the role of a trustworthy authority (the judge, the jury) neutrally evaluating the evidence in an objective, fact-based manner in which legal rules are consistently applied and where prejudice and bias are minimized or even eliminated. ${ }^{137}$

However, it is striking that the respondents' reactions to the CEC procedure were based upon very different procedural issues than those shaping reactions to lawsuits. If respondents simply brought their views about legal procedures, derived from lawsuits, to the evaluation of this new procedure (which, as noted above, few respondents had used) then they should consider the same issues in evaluating both procedures. Instead, they evaluated the CEC procedure very differently.

The two procedural factors that mattered most concerning the CEC procedure were voice and respect. ${ }^{138}$ Hence, respondents thought about this procedure in a way that is distinct from their general frame for evaluating lawsuits. They focused upon whether they would have a chance to present their views and whether they would be treated with

134. See infra appended Table 4. Appended Table 4 shows the strength of the statistical relationship between judgments that a procedure is desirable and judgments about its attributes. The statistic is the correlation (r). An $r$ of zero suggests no relationship, while an $r$ of 1 indicates a complete correspondence (e.g., gender and being able to give birth).

135. Infra appended Table 4; see also Survey Results, supra note 64.

136. See infra appended Table 4.

137. See, e.g., THIBAUT \& WALKER, supra note 21 , at 1 (covering "methods or procedures that may be used to resolve conflicts that arise between individuals and between groups").

138. See infra appended Table 4. 
respect and courtesy. These findings are important because they suggest that, in some cases, a process that highlights these features may be effective in enhancing government legitimacy and increasing citizen involvement.

To explore the importance of this finding, we need to consider the issues that mattered in each case. With the CEC procedure, respondents focused upon whether the procedure provides "an opportunity to present your arguments orally"; whether everyone's rights are respected; and whether those involved are treated with dignity and respect. ${ }^{139}$ These issues are related to the quality of interpersonal treatment.

With lawsuits, respondents cared about "decisions based upon the facts"; "decision[s] reflecting a consistent application of the law"; "a neutral decision"; "an appropriate decision in terms of [legal] liability"; a decision "fair to everyone involved"; "a decision that provides adequate opportunities to appeal"; "a decision based upon an adequate consideration of your arguments by the decision maker"; and "a decision in which the authorities adequately explain their reasoning." 140 These issues are centered on the view that the decision is appropriate and reasonable. They are issues linked to the quality of decision-making.

Each of these two aspects of procedures - quality of interpersonal treatment and quality of decision-making - contributes to judgments about the fairness of legal procedures. ${ }^{141}$ Quality of treatment involves treatment with politeness and dignity, concern for people's rights, and other aspects of procedures that are not directly linked to the decisions being made through the procedure. ${ }^{142}$ Quality of decision-making by authorities emphasizes issues of decision-maker neutrality, the objectivity and fact-based quality of decision-making, and the consistency of rule application. ${ }^{143}$

The finding that interested citizens may value different procedures for different reasons also suggests that such citizens may prefer one

139. See Survey Results, supra note 64.

140. See id.

141. TYLER \& HUO, supra note 103, at 95-96 (Tyler and Huo considered the importance of these factors in shaping judgments about the overall justice in personal experiences with legal authorities. They found that both the quality of decision-making and the quality of interpersonal treatment are more important than outcome favorability in shaping judgments about the justice of the experience) These two aspects of procedure also are obviously not necessarily entirely distinct.

142. See Blader \& Tyler, A Four-Component Model, supra note 132; Steven L. Blader \& Tom R. Tyler, What Constitutes Fairness in Work Settings? A Four-Component Model of Procedural Justice, 13 Hum. Resource MGMT. ReV. 107 (2003) [hereinafter Blader \& Tyler, What Constitutes Fairness?].

143. Blader \& Tyler, A Four-Component Model, supra note 132; Blader \& Tyler, What Constitutes Fairness?, supra note 142. 
procedure in one context because its predominant features are perceived to be particularly important in that context, while they may prefer another procedure in a different setting, for the same reason.

It may be helpful to consider the comparison of lawsuits and mediation. When mediation was first introduced in court settings, people did not want to use it. ${ }^{144}$ They came to court with litigation in mind. ${ }^{145}$ When court systems required pre-trial mediation, however, the courts found that many cases were resolved in mediation and, when people participated in mediation, they rated it as more satisfactory than a trial, irrespective of whether their case was resolved. ${ }^{146}$ In other words, once people experienced the procedure, they liked it. This suggests the possibility that, although people are not asking for the CEC procedure, or procedures with elements that highlight procedural justice features such as voice and respect, they might value such a process if they used it.

\section{OVERALL CONCLUSIONS}

One question we sought to explore in this paper involves the possible role of procedural justice concepts, as well as distributive justice, in creating citizen interest in using legal procedures. Respondents indicated that, in the case of lawsuits, procedural influences are similar in strength to the influence of the likelihood that a procedure would yield a desirable outcome. $^{147}$ For example, procedural desirability is shaped by outcome control $(r=0.49)$, but equally strongly by procedural justice $(r=0.50)$, neutrality $(\mathrm{r}=0.50)$, and trust in the decision maker $(\mathrm{r}=0.45) .{ }^{148}$ Procedural influences were weaker for the CEC process. ${ }^{149}$ The analyses reported reinforce the argument that people react favorably to the fairness of procedures and show that these fairness judgments are distinct from the desire to obtain a particular outcome. People can and do distinguish procedural fairness from winning, and even from having things come out right (i.e., achieving distributive justice). The fact that

\footnotetext{
144. See, e.g., Tyler et al., supra note 21 at 99-118.

145. Id.

146. Id. at 429-30.

147. Ideally we would be able to consider the influence of both factors simultaneously using regression analysis. However, the small size of the sample does not allow for this type of analysis.

148. See infra appended Table 4.

149. Id.
} 
respondents value procedural justice features suggests it is worth considering these features in process design.

Beyond this finding, which is supported by previous research in other settings, two of the intriguing findings from the questionnaire responses are that (1) respondents attach different value to the same procedure in different contexts, and (2) respondents value different procedures for different reasons-namely, individuals like particular features best in certain procedures while they prefer different features in other mechanisms.

The key insight from these findings is that context seems to matter in terms of citizen satisfaction - that is, it may be that no set of features will be valued uniformly in different contexts and, further, different features will be valued more or less highly depending on the process involved. These findings suggest the value of targeted, context-specific follow-up research to develop more sophisticated understandings of citizen preferences for procedures.

We believe the approach we have modeled in this project can be followed to assess procedural options in different contexts in which there is an interest in encouraging meaningful citizen engagement. That is, interested stakeholders (some appropriate subset of the universe of likely participants) can be asked about their preferences for different procedures in a particular context and, further, about their preferences for different features of processes; policy makers can then incorporate this information into their efforts to design processes that will be responsive to these desires, in addition to considering other relevant factors as part of such design work. ${ }^{150}$

We suggest it may be possible to consider a matrix approach for designing suitable procedures for different situations, again to the extent the goal is to engage citizens in such procedures. The following matrix is a simplification of what we are looking for, but it hopefully is illustrative of the type of inquiry that may be helpful. It reflects our speculation that development of typologies for at least four variables in dispute resolution contexts may help to advance capacity to tailor procedures to the interests of concerned citizens: (1) the personal

150. Even in the limited context of seeking to enhance citizen engagement, this ex ante approach has limits. An example of those limits is provided by the literature on mediation. People do not seek mediation in courts, thinking they prefer adjudication. If required to engage in mediation, however, many people find it engaging, and, overall, mediation is rated post-use as more satisfactory than adjudication. However, the features that make mediation popular post-use are not the same features that people seek when they come to court. Further, process design obviously needs to consider a wide variety of factors beyond the impacts of different options on likely levels of citizen participation. See, e.g., supra note 12 . 
characteristics of likely process participants; (2) the potential clarity of the outcome; (3) the contentiousness of the issues; and (4) how much is at stake. ${ }^{151}$

The Impact of Situational Issues and Stakeholder Characteristics on the Weight Placed upon Different Procedural Elements

\begin{tabular}{|c|c|c|c|}
\hline \multirow[b]{2}{*}{$\begin{array}{l}\text { Personal } \\
\text { characteristics }\end{array}$} & \multicolumn{3}{|c|}{ Contextual issues } \\
\hline & $\begin{array}{l}\text { Potential clarity } \\
\text { of the outcome }\end{array}$ & $\begin{array}{l}\text { Contentiousness } \\
\text { of the issues }\end{array}$ & $\begin{array}{l}\text { How much is at } \\
\text { stake? }\end{array}$ \\
\hline $\begin{array}{l}\text { The person's } \\
\text { motivation for } \\
\text { taking action }\end{array}$ & $\begin{array}{l}\text { Weight placed } \\
\text { upon: } \\
\text {-neutrality } \\
\text {-trust } \\
\text {-respect } \\
\text {-voice } \\
\text {-overall } \\
\text { procedural } \\
\text { justice }\end{array}$ & $\begin{array}{l}\text { Weight placed } \\
\text { upon: } \\
\text {-neutrality } \\
\text {-trust } \\
\text {-respect } \\
\text {-voice } \\
\text {-overall } \\
\text { procedural } \\
\text { justice }\end{array}$ & $\begin{array}{l}\text { Weight placed } \\
\text { upon: } \\
\text {-neutrality } \\
\text {-trust } \\
\text {-respect } \\
\text {-voice } \\
\text {-overall } \\
\text { procedural } \\
\text { justice }\end{array}$ \\
\hline $\begin{array}{l}\text { Trust in the } \\
\text { government }\end{array}$ & $\begin{array}{l}\text { Weight placed } \\
\text { upon: } \\
\text {-neutrality } \\
\text {-trust } \\
\text {-respect } \\
\text {-voice } \\
\text {-overall } \\
\text { procedural } \\
\text { justice }\end{array}$ & $\begin{array}{l}\text { Weight placed } \\
\text { upon: } \\
\text {-neutrality } \\
\text {-trust } \\
\text {-respect } \\
\text {-voice } \\
\text {-overall } \\
\text { procedural } \\
\text { justice }\end{array}$ & $\begin{array}{l}\text { Weight placed } \\
\text { upon: } \\
\text {-neutrality } \\
\text {-trust } \\
\text {-respect } \\
\text {-voice } \\
\text {-overall } \\
\text { procedural } \\
\text { justice }\end{array}$ \\
\hline $\begin{array}{l}\text { Capacity to } \\
\text { participate } \\
\text { (e.g., to make } \\
\text { oral or } \\
\text { written } \\
\text { arguments) }\end{array}$ & $\begin{array}{l}\text { Weight placed } \\
\text { upon: } \\
\text {-neutrality } \\
\text {-trust } \\
\text {-respect } \\
\text {-voice } \\
\text {-overall } \\
\text { procedural } \\
\text { justice }\end{array}$ & $\begin{array}{l}\text { Weight placed } \\
\text { upon: } \\
\text {-neutrality } \\
\text {-trust } \\
\text {-respect } \\
\text {-voice } \\
\text {-overall } \\
\text { procedural } \\
\text { justice }\end{array}$ & $\begin{array}{l}\text { Weight placed } \\
\text { upon: } \\
\text {-neutrality } \\
\text {-trust } \\
\text {-respect } \\
\text {-voice } \\
\text {-overall } \\
\text { procedural } \\
\text { justice }\end{array}$ \\
\hline
\end{tabular}

151. Our model matrix is a simplification of possible citizen perspectives for several reasons This is an initial effort intended to stimulate refinements that will help to produce inventories of the types of variables relevant in different contexts, among different stakeholders, in engendering meaningful citizen participation. For example, the matrix in the text only allows for evaluating citizen preferences for different procedures in single contextual situations. It is possible to extend our model approach to develop matrices that account for different contextual scenarios taken together. Similarly, it is possible to account for the importance of outcome by incorporating a distributive justice column in the matrix. 
As this preliminary effort at a matrix reflects, one key variable involves the traits or characteristics of likely participants. The point here is that different disputes involve different groups of stakeholders and, further, different procedures may be more or less attractive depending on the preferences of the particular groups involved. The notion that we should consider the attributes of users in designing procedures is well established in law. In the procedural due process context, for example, the United States Supreme Court in cases such as Mathews v. Eldridge and Goldberg v. Kelly has focused particular attention on the characteristics of participants in determining appropriate procedures. ${ }^{152}$ As the Court in Mathews noted, due process requires that procedures be tailored "to "the capacities and circumstances of those who are to be heard'...."153 In our situation, the focus is on the likelihood that particular features will engage specific constituencies, rather than on due process implications as in Goldberg and Mathews, but the general idea is the same; notably that it is appropriate to consider the nature of stakeholders in designing procedures. Thus, a typology of likely participants may be helpful in designing procedures intended to engage them. Not much work has been done in this arena, but for an interesting example of an effort to distinguish among different environmental NGOs in terms of their interests, see Mark Seidenfeld, Empowering Stakeholders: Limits on Collaboration as the Basis for Flexible Regulation. $^{154}$ Further work is needed to begin to develop such a typology.

We hypothesize that a second key variable in designing dispute resolution processes so they are effective in engaging citizens is the nature of the dispute itself. In other words, the type of dispute may affect the relative importance to participants of different procedures (and features of processes). Thus, again we suggest the value of a typology, but this time of different types of disputes. In developing this hypothesis, it will be important to unpack differences among types of disputes to determine the differences that matter to likely participants in terms of their preferences among various procedures. We offer a few possible distinguishing features in an effort to explain what we mean. We hypothesize, for example, that a highly contentious dispute may lead participants (or would-be participants) to prefer different procedures than less contentious disputes. Similarly, participants may have stronger preferences for certain features in disputes in which the law is unclear

152. Mathews v. Eldridge, 424 U.S. 319 (1976); Goldberg v. Kelly, 397 U.S. 254 (1970).

153. Mathews, 424 U.S. at 349 (quoting Goldberg, 397 U.S. at 268-69).

154. See Seidenfeld, supra note 81 . 
than in disputes where the governing law is relatively clear. So, for example, it may be that a procedure like the CEC process, which appears to be valued for its "voice" and "respect" features, may be valued relatively highly by participants where outcomes are clear. Again, follow-up work is needed to explore the details of such a typology-the distinctions among different types of disputes that are relevant to participants' preferences for different types of procedures. ${ }^{155}$

Finally, we suggest that the type of end result a process produces also may be relevant in identifying the absolute and relative importance of different procedural justice features to likely participants in such a process. If the stakes are high, for example, our hypothesis is that certain procedural justice features more closely related to outcome may carry particular importance, while less outcome-related features such as voice may receive a greater degree of preference for low-stakes disputes. ${ }^{156}$ While our data is obviously inconclusive, the fact that the CEC process does not produce a clear outcome and carries no sanctions or other formal relief offers a possible explanation for why respondents especially valued softer procedural justice features, such as voice, for this process. By contrast, they valued outcome-related features for citizen suits where the stakes, at least in immediate respects such as the prospect of monetary penalties, injunctive relief, and recovery of attorneys' fees, are higher. ${ }^{157}$ In short, another aspect of a matrix intended to gauge relative preferences for different procedural justice features may be the outcomes the process is intended to yield. Because in many situations process design is constrained in terms of possible outcomes, these types of constraints may influence participant perception of the utility or importance of different procedural justice features. As a result, it seems productive in seeking to improve decision-making processes in terms of their ability to engage citizens to consider the influence of possible outcomes on citizens' preferences among procedural features.

155. In Mathews, for example, the Court focused on the role of factors such as credibility and veracity in the decision-making process in evaluating the adequacy of different procedures. 424 U.S. at 325 .

156. Mathews also focused on outcome in the due process context, concluding that pretermination process is more important in the welfare context than in the disability benefits context because welfare assistance is "given to persons on the very margin of subsistence ...." Id. at 340 The Mathews Court also included governmental interests in its three-part test, a factor that those engaged in process design obviously need to consider as well. See id. at 321. Interestingly, procedural justice studies do not generally find that people care more about procedural issues when the stakes are low. When stakes are high people continue to view the fairness of procedures as an important issue. See generally Lind \& TYLER, THE Social PSYChOlOgY, supra note 116 (reviewing the research literature on procedural justice). However, here we are suggesting that people may focus on different aspects of procedures under different conditions.

157. See supra Part II. 
We do not pretend to have fully considered the possible uses creative process designers may make of improved understandings of citizen preferences for different types of procedures and process features in particular contexts. Perhaps the most straightforward use of insights of this sort is to reconfigure a process (while also taking into account other important design parameters such as cost, resources, etc.) so that likely users of the process are more apt to find it attractive. We can easily envision other possible uses of this information as well. For example, it is possible that processes may have synergistic effects, so that a process strong on some features may not only lead to satisfied users but also, in the best case, operate to enhance users' perspectives concerning other processes as well. As noted above, pre-litigation mediation seems to offer a possible example of this phenomenon. Many courts require people to use mediation prior to engaging in litigation. ${ }^{158}$ Often, parties are able to settle their disputes through this mechanism and they find such a process, even with its lower entry barriers and lower costs, quite satisfactory. Further, even for disputants who use mediation initially but do not resolve their dispute through such a process and instead move forward to litigation, the mediation experience is such that disputants nevertheless are more positive about the litigation experience than those disputants who did not first participate in mediation. ${ }^{159}$ Thus, there is a possibility that a process that rates highly in terms of certain procedural justice features (e.g., voice and respect) may help to engender higher confidence in procedures that lack these features but are attractive for other reasons.

To sum up, how governance institutions should be structured remains a hot topic conceptually as well as in the field. ${ }^{160}$ Would-be and

158. See supra notes $144-46$ and accompanying text.

159. The benefit for the legal system lies in the likelihood of reducing the adverse consequences of a culture of litigation. One of the interesting findings of the mediation literature is that, when people have pre-trial mediation that fails and then go on to litigation, their rates of accepting litigation outcomes increase. Even failed mediation, in other words, has a positive influence on the long-term likelihood of finding an acceptable solution through litigation. See Tom R. Tyler, Social Justice: Outcome and Procedure, 35 INT'L J. PSYCHOL. 117, 119-20 (2000).

160. See, e.g., Jody Freeman, Collaborative Governance in the Administrative State, 45 UCLA L. REV. 1, 3, 6 (1997) (suggesting that "the language of regulatory reinvention is ubiquitous" because of concerns about the structure and operation of the administrative state, and that there is a need to focus on collaborative approaches that will facilitate adaptive problem solving); Christopher S. Elmendorf, Advisory Counterparts to Constitutional Courts, 56 DuKE L.J. 953, 955 (2007) (discussing creation of new, independent institutions "which... are concerned with foundational commitments of liberal democracy" but are intended to advance this commitment through strategies such as investigations, rather than traditional litigation). Elmendorf refers to these institutions as "advisory counterparts" to constitutional courts. Id. The CEC citizen submissions process is an example of such an advisory counterpart. In the environmental arena that is the focus of this article, there are increasing numbers of examples of regional and other new forms of governance structures 
actual architects or implementers of institutional restructuring have a variety of goals, including enhancing government's legitimacy and credibility, improving effectiveness and efficiency, increasing citizen engagement, and bolstering willingness to defer to government decisionmaking processes and conform to governmental expectations. ${ }^{161}$

Our argument in this article is that empirical governance is a useful tool for those interested in such reforms. Our particular focus is on the issue of citizen involvement in governance, notably on citizens' use of governance mechanisms intended to engage them. If we want people to participate in government, it is important to structure procedures to encourage such participation. People always have a choice about how to respond to evidence of wrongdoing. One choice is to respond through the legal system. Alternatively, they can become disaffected and withdraw from active governance. They can choose strategies such as mounting a media campaign, waging civil disobedience, or starting a revolution. On a broad scale, when people do not view the procedures available within the legal system as desirable and appropriate, people do not bring their disputes to the legal system and the credibility of our institutions of governance, along with the authority of the law to manage contentious issues, are diminished. ${ }^{162}$ Our thesis in this context is that

created to address common environmental concerns, sometimes organized around a common resource, and other times focused on larger issues. See, e.g., Robert W. Adler, Addressing Barriers to Watershed Protection, 25 ENVTL. L. 973, 1071 (1995) (discussing the Chesapeake Bay Program); Scott D. Anderson, Watershed Management and Nonpoint Source Pollution: The Massachusetts Approach, 26 B.C. ENVTL. AFF. L. REV. 339, 377 (1999) (discussing the Massachusetts Watershed Initiative); Katherine Fletcher, Protecting Puget Sound: An Experiment in Regional Governance, 65 WASH. L. REV. 359, 366 (1990) (discussing the Puget Sound plan); Errol Meidinger, The Administrative Law of Global Private-Public Regulation: The Case of Forestry, 17 EUR. J. INT'L L. 47, 48 (2006) (discussing the Forest Stewardship Council).

161. These issues have been particularly salient in local courts and with trial judges seeking to better manage their dockets. The California courts, for example, recently adopted a strategic plan for the judicial branch that is focused upon issues of justice for litigants. See JUDICIAL COUNCIL OF CAL., Justice IN Focus: The StRATEgIC Plan FOR CALIFORNIA's JUDiCIAL BRANCH 2006-2012 (2006), available at http://www.courtinfo.ca.gov/reference/documents/strategic_plan_20062012.pdf. The plan was based upon statewide surveys that identified procedural justice issues as the primary concern expressed by the public. D.B. Rottman, JUDICIAL COUNCIL OF CAL., TRUST AND CONFIDENCE IN THE CALifornia COURTS: A SuRvey of The PubliC AND ATtORneys (2005), available at http://www.courtinfo.ca.gov/reference/documents/4_37pubtrust1.pdf. Such a procedural justice approach has also been advocated by judicial authorities. See, e.g., Kevin Burke \& Steve Leben, Procedural Fairness: A Key Ingredient in Public Satisfaction (Sept. 26, 2007). Primers on implementing these ideas can be found in Tom R. Tyler, What Do They Expect?: New Findings Confirm the Precepts of Procedural Fairness, CAL. CTS. ReV., Winter 2006, at 2224; Jud. Council of CAl., Procedural FAirness IN THE CAlifornia Courts (2007), available at http://www.courtinfo.ca.gov/programs/profair/.

162. There are, of course, limits to the role the legal system should play in resolving disputes. Notions such as rational ignorance and its impact on citizen interest in participation are beyond the scope of this paper, as is the appropriate role for extra-legal approaches such as civil disobedience in 
empirical governance, notably systematically studying the preferences of likely process users in different contexts, can help us learn about the types of processes interested stakeholders would be inclined to use and, more particularly, the types of features that are likely to increase such participation. ${ }^{163}$

addressing conflict. For an overview of rational ignorance, see Mark A. Lemley, Rational Ignorance at the Patent Office, 95 Nw. U. L. REV. 1495, 1497 n.6 (2001).

163. As we have noted, one problem is that people may not know how they will feel about a procedure until they have used it. Since very few people have used the CEC procedure, we were not able to evaluate whether using the procedure changed people's views about it. As we have noted, people are much more likely to view mediation as satisfactory after they have used it. See supra note 146 . 
Table 1

Desirability of Availability of Various Procedures

\begin{tabular}{|c|c|}
\hline Procedure & Mean (Standard Deviation) \\
\hline File a citizen lawsuit & $5.89(0.58)$ \\
\hline Participate in government enforcement action & $5.30(1.07)$ \\
\hline File a common law action & $5.42(1.17)$ \\
\hline File a submission with the CEC & $4.12(1.59)$ \\
\hline File a citizen suit against the government & $5.74(0.53)$ \\
\hline Raise concerns with the EPA & $4.78(1.12)$ \\
\hline Petition the EPA to withdraw state authorization & $5.30(0.87)$ \\
\hline Informal contact with the violator & $4.26(1.56)$ \\
\hline Informal contact with the government & $5.37(0.79)$ \\
\hline Pursue shaming opportunity & $4.88(1.56)$ \\
\hline Take other action & $5.04(1.60)$ \\
\hline
\end{tabular}

Note: $\mathrm{N}=30$. Scale $1=$ very unimportant; $6=$ very important. 
Table 2

Likelihood of Using Various Procedures to Resolve Environmental Disputes

\begin{tabular}{|c|c|c|c|}
\hline & Number of survey & $\begin{array}{l}\text { Individual is } \\
\text { violating the law }\end{array}$ & $\begin{array}{l}\text { Widespread } \\
\text { violations }\end{array}$ \\
\hline Procedure & with procedure & $\begin{array}{l}\text { Mean (Standard } \\
\text { Deviation) }\end{array}$ & $\begin{array}{l}\text { Mean (Standard } \\
\text { Deviation) }\end{array}$ \\
\hline File a citizen lawsuit & 1 & $4.93(1.41)$ & $4.13(1.55)$ \\
\hline $\begin{array}{l}\text { Participate in government } \\
\text { enforcement action }\end{array}$ & 1 & $3.31(1.62)$ & $3.89(1.50)$ \\
\hline $\begin{array}{l}\text { File a common law } \\
\text { action }\end{array}$ & 2 & $2.96(1.40)$ & $2.93(1.21)$ \\
\hline $\begin{array}{l}\text { File a submission with } \\
\text { the CEC }\end{array}$ & 6 & $2.21(1.38)$ & $2.36(1.44)$ \\
\hline $\begin{array}{l}\text { File a citizen suit against } \\
\text { the government }\end{array}$ & 1 & $3.52(1.68)$ & $4.11(1.40)$ \\
\hline $\begin{array}{l}\text { Raise concerns with the } \\
\text { EPA }\end{array}$ & 2 & $3.18(1.68)$ & $3.65(1.62)$ \\
\hline $\begin{array}{l}\text { Petition EPA to withdraw } \\
\text { state authorization }\end{array}$ & 2 & $3.18(1.54)$ & $3.89(1.37)$ \\
\hline $\begin{array}{l}\text { Informal contact with the } \\
\text { violator }\end{array}$ & 2 & $3.32(1.66)$ & $2.88(1.56)$ \\
\hline $\begin{array}{l}\text { Informal contact with the } \\
\text { government }\end{array}$ & 2 & $4.11(1.69)$ & $3.86(1.69)$ \\
\hline $\begin{array}{l}\text { Pursue shaming } \\
\text { opportunity }\end{array}$ & 2 & $4.07(1.71)$ & $4.39(1.55)$ \\
\hline Take other action & N/A & $4.22(1.70)$ & $4.00(1.71)$ \\
\hline
\end{tabular}

Note: $\mathrm{N}=30$. Scale $1=$ very unlikely; $6=$ very likely. 
Table 3

Desirable Attributes of a Procedure

\begin{tabular}{|c|c|}
\hline Attributes & Mean \\
\hline Procedural Justice & 5.18 \\
\hline Provide a generally fair procedure & 5.18 \\
\hline Neutrality & 5.58 \\
\hline Lead to a decision based on facts & 5.88 \\
\hline Lead to a decision reflecting a consistent application of the law & 5.39 \\
\hline Provide adequate opportunities to appeal & 5.43 \\
\hline Lead to an appropriate application of the law to legal liability & 5.64 \\
\hline Lead to a decision fair to everyone involved & 4.57 \\
\hline Trust & 5.16 \\
\hline $\begin{array}{l}\text { Lead to a decision based upon an adequate consideration of your } \\
\text { concerns }\end{array}$ & 5.33 \\
\hline $\begin{array}{l}\text { Lead to a decision in which the authorities adequately explained their } \\
\text { reasons }\end{array}$ & 4.96 \\
\hline Respect & 4.73 \\
\hline Respect everyone's rights & 4.93 \\
\hline Treat those involved with dignity and courtesy & 4.54 \\
\hline Voice & 4.40 \\
\hline Provide an opportunity to present arguments in writing & 4.64 \\
\hline Provide an opportunity to present arguments orally & 4.21 \\
\hline Enable you to have dialogue with the other party & 4.00 \\
\hline Enable you to have dialogue with the decision maker & 4.74 \\
\hline Control over the outcome & 5.51 \\
\hline $\begin{array}{l}\text { Provide you a way to effectively change the behavior to which you } \\
\text { object }\end{array}$ & 5.71 \\
\hline Help you get the outcome you wanted & 5.43 \\
\hline Give you some control over the outcome & 5.39 \\
\hline
\end{tabular}

Note: $\mathrm{N}=30$. Scale: $1=$ very unimportant; $6=$ very important. 
Table 4

Desirable Attributes Related to Citizen Lawsuits and CEC Citizen Submissions Process

\begin{tabular}{|c|c|c|c|c|c|c|c|c|}
\hline \multirow[b]{3}{*}{ Attribute } & \multirow{3}{*}{$\begin{array}{c}\text { Lawsuit } \\
\text { alpha }\end{array}$} & \multirow{3}{*}{$\begin{array}{l}\text { CEC } \\
\text { alpha }\end{array}$} & \multicolumn{2}{|c|}{ Single Party } & \multicolumn{2}{|c|}{ Multiple Party } & \multicolumn{2}{|c|}{ Overall } \\
\hline & & & Lawsuit & CEC & Lawsuit & CEC & Lawsuit & CEC \\
\hline & & & $\mathbf{r}$ & $\mathbf{r}$ & $\mathbf{r}$ & $\mathbf{r}$ & $\mathbf{r}$ & $\mathbf{r}$ \\
\hline Neutrality & 0.94 & 0.81 & $0.56^{* *}$ & 0.03 & 0.36 & -0.01 & $0.50 * *$ & 0.06 \\
\hline $\begin{array}{l}\text { Trust } \\
\text { decision } \\
\text { maker }\end{array}$ & 0.75 & 0.67 & $0.52 * *$ & 0.31 & 0.30 & 0.21 & $0.45^{*}$ & 0.39 \\
\hline $\begin{array}{l}\text { Treated with } \\
\text { respect, } \\
\text { courtesy }\end{array}$ & 0.75 & 0.63 & 0.31 & $0.47^{*}$ & 0.20 & $0.41^{*}$ & 0.28 & $0.48^{*}$ \\
\hline Voice & 0.75 & 0.66 & 0.09 & $0.52 *$ & 0.26 & $0.41 *$ & 0.20 & $0.58 * *$ \\
\hline $\begin{array}{l}\text { Control over } \\
\text { outcome }\end{array}$ & 0.82 & 0.45 & $0.52 * *$ & $0.45^{*}$ & 0.38 & $0.43^{*}$ & $0.49 * *$ & $0.42 *$ \\
\hline $\begin{array}{l}\text { Rated } \\
\text { procedural } \\
\text { justice }\end{array}$ & - & - & $0.52 * *$ & 0.28 & $0.39 *$ & 0.25 & $0.50 * *$ & 0.28 \\
\hline Adj. R-sq. & - & - & $39 \% * *$ & $31 \%$ & $14 \%$ & $45 \%$ & $36 \% *$ & $44 \%$ \\
\hline
\end{tabular}

Note: The numbers shown in this table refer to correlation coefficient r. The adjusted R.-sq. is for an equation that includes all of the indices entered at one time.

Twenty-four of thirty respondents indicated they had been involved in lawsuits; two indicated they had used the CEC procedure.

$* \rho<0.05$

$* * \rho<0.01$ 